\title{
PENELITIAN TANAH SEBAGAI PENDUKUNG PENGEMBANGAN INSTALASI PENGOLAHAN LIMBAH CAIR DOMESTIK DI KANTOR BPP TEKNOLOGI
}

\author{
Taty Hernaningsih \\ Pusat Teknologi Lingkungan, BPPT \\ Jln. MH. Thamrin No.8 Jakarta Pusat. Gedung II Lt.20
}

\begin{abstract}
Domestic wastewater from the regional office in Jakarta is one of the contributors to environmental pollution. Many office buildings in Jakarta are not managing the domestic wastewater, except BPP Technology office has managed its domestic wastewater by building domestic wastewater treatment plant. Increasing officers caused decrease performance and unsufficient capacities of WWTP. WWTP expansion is needed to address the problem of environmental pollution. The success of the development of WWTP is determined by input data (soil research data) with high accuracy, design, and construction. Number of failures of civil construction in recent years due to the use of land in excess of eksploitatif carrying capacity in general, for example, groundwater exctraction in excess can cause degradation of land, construction of road above the critical height cause sliding and high buildings construction affect to the surrounding land. The research of the soil is required for the planning of WWTP BPP Teknologi. The study was to estimate the soil carrying capacity of the soil layers that had been done by conducting experiments such as the SPT (Standard Penetration Test), Sounding and Boring. Implementation of activities include soil testing in the field and soil testing in the laboratory, physical test and mechanical test, test to determine the value of ground forces. Sondir was conducted in three locations until the impermeable soil and drilling was implemented in depth of 4,00 m.. Four tubes of soil samples consisting disturbed soil and undisturbed soil from depth of 1,5 m-2,00 m and 3,00 m-3,50 m were taken from drilling to be analyzed in the laboratory.
\end{abstract}

Keywords: IPAL, soil sounding and boring, Cone penetration test, pemampatan tanah

\section{PENDAHULUAN}

\subsection{Latar Belakang}

Pencemaran air banyak terjadi di daerah perkotaan khususnya daerah perkantoran yang jumlahnya makin padat dan jumlah pegawainya makin bertambah. Umumnya pencemaran ini berupa pencemaran limbah domestik yang berasal dari WC, urinoir dan kantin. Di kota Jakarta banyak perkantoran yang belum mengelola limbah domestik cairnya. Dalam mengatasi masalah pencemaran air di lingkungan diperlukan instalasi pengolahan limbah yang dapat mengolah limbah domestik sampai kualitas yang diijinkan oleh Pemda Dki Jakarta. Kantor BPP Teknologi yang berlokasi di Jl. Thamrin 8, Jakarta Pusat terdapat 3.000 pegawai, saat ini sudah mempunyai Instalasi Pengolahan Limbah Cair (IPAL) domestik. Dengan adanya pertambahan pegawai maka kinerja IPAL menjadi tidak baik dan kapasitasnya sudah tidak memadai. Oleh karena itu diperlukan pengembangan IPAL domestik untuk mengatasi permasalahan yang ada.

Dalam rangka pengembangan IPAL BPP Teknologi ini maka telah direncanakan modifikasi terhadap IPAL yang ada. Keberhasilan pelaksanaan suatu pembangunan IPAL domestik ini sangat ditentukan oleh : input data (data penelitian tanah) dengan ketelitian yang tinggi, perencanaan (dokumen kontrak/ gambar) yang mantap, dan pelaksanaan konstruksi dengan metode kerja yang tepat serta kontrol/pengawasan pada saat pelaksanaan dilakukan secara ketat.

Seperti diketahui penyebab banyaknya kegagalan konstruksi bangunan sipil pada akhirakhir ini disebabkan oleh eksploitatifnya pemanfaatan tanah yang melebihi daya dukung tanah secara umum, sebagai contoh : pengambilan air tanah dalam yang berlebihan dapat menyebabkan penurunan tanah, pembangunan jalan raya dengan timbunan yang melebihi tinggi kritis sehingga dapat menyebabkan sliding atau kelongsoran dan pembangunan gedung bertingkat tinggi yang mempengaruhi kondisi tanah sekitarnya. Untuk memperkecil permasalahan-permasalahan tersebut di atas dalam pembangunan IPAL domestik di BPP Teknologi perlu didukung dengan "Penelitian Tanah" pada saat perencanaan,

Penelitian tanah ini untuk memperkirakan daya dukung lapisan tanah tersebut yang dapat dilakukan dengan melakukan percobaan seperti SPT (Standard Penetrasi Test), Sondir (sounding) dan Pemboran (Boring). Untuk mendapatkan data yang cukup teliti dan lengkap harus dilakukan penyelidikan tanah yang 
terperinci, yang berarti tidak hanya berdasarkan satu jenis percobaan saja. Sebaiknya penyelidikan tersebut diperoleh dengan membandingkan beberapa percobaan seperti yang tersebut di atas. Disamping untuk mendapatkan data yang teliti tergantung pada ketepatan pemilihan alat yang dipakai misalnya sondir tidak tepat digunakan pada lapisan tanah yang mengandung lapisan kerikil dan batuan. Sedangkan pemboran tidak dapat dilaksanakan pada lapisan tanah yang lunak dan mudah lepas, yang akan mengalami keruntuhan yang tanah.

Dalam makalah ini akan dijelaskan penelitian tanah untuk keperluan perancangan pondasi IPAL domestik BPP Teknologi yang terdiri atas uji tanah di lapangan dan uji tanah di laboratorium, baik itu berupa uji fisik maupun uji mekanik, uji untuk mengetahui angka kekuatan tanah.

\subsection{Tujuan dan Sasaran}

Tujuan penyelidikan tanah ini dimaksudkan untuk mengetahui sifat-sifat fisis dan sifat-sifat fisik dari lapisan tanah serta kedalaman lapisan tanah keras pada area yang akan dibangun IPAL domestik. Sifat-sifat fisis dan sifat-sifat fisik yaitu berupa klasifikasi tanah, sifat konsistensi tanah, daya dukung tanah dengan menggunakan alat tes sondir sampai dikedalaman lapisan tanah keras untuk nilai daya dukung tahanan ujung konus dan tahanan geser maksimum sebesar $250 \mathrm{~kg} / \mathrm{cm}^{2}$ atau maksimum di kedalaman $20 \mathrm{~m}$.

Adapun yang menjadi sasaran adalah mendapatkan data sondir dan pemboran yang dapat digunakan sebagai:

a. Penentuan lapisan tanah yang harus dibuang dan diganti dengan tanah yang lebih baik dan dipadatkan dan kontrol kepadatan tanah timbunan.

b. Perencanaan pondasi dan perhitungan settlement.

c. Perencanaan stabilitas lereng galian atau timbunan dan lain-lain

Lokasi penelitian dilaksanakan pada area rencana pengembangan bangunan Instalasi Pengolahan Limbah Cair Domestik yaitu di halaman belakang di BPP Teknologi, JI. M.H. Thamrin no.8, Jakarta Pusat. Lokasi penelitian ini dapat dilihat pada gambar 1 .

\section{METODOLOGI DAN PERALATAN}

\subsection{Metodologi}

Metodologi ini meliputi uji fisik maupun uji mekanik, uji untuk mengetahui angka kekuatan tanah. Uji tanah di lapangan diperlukan untuk mencari data langsung dari lapangan. Uji ini dapat berupa uji lapisan tanah dengan alat bor (soil pemboran), uji kepadatan maupun kekerasan tanah. Uji Kekerasan tanah dapat berupa uji penetrasi standar (standard penetration test), uji sondir atau uji penetrasi konus (Cone penetration test). Uji lapangan ini termasuk pelaksanaan pengambilan sampel tanah untuk keperluan uji laboratorium. Sedangkan untuk uji di laboratorium dapat berupa analisa butiran dan komposisi butiran/ gradasi, kadar air, berat isi, berat jenis (specific gravity) uji geser dengan alat geser langsung maupun dan alat triaxial hingga uji pemampatan tanah (consolidation test).

Untuk menentukan letak dan banyaknya titik bor dan sondir suatu pembangunan banyak ditentukan oleh: jenis dan karakteristik sruktur bangunan atas yang direncanakan, keanekaragaman sruktur geologi dan kondisi topografi daerah setempat, serta lokasi atau daerah yang dianggap kritis $^{(4)}$. Paling sedikit penelitian 1 lubang bor harus dibuat tiap luas area $2500 \mathrm{ft}^{2}$ dan 1 lubang bor untuk pembuatan gedung dengan luas minimum $1600 \mathrm{ft}^{2}$. Sesuai dengan perencanaan IPAL dalam kegiatan ini dilakukan penelitian 3 lokasi sondir dan 1 sumur bor.

Metodologi penelitian lapisan tanah di lapangan ini meliputi:

\section{a. Sondir / CPT (Cone Penetration Test)}

Pelaksanaan penyondiran dilakukan pada titik sondir yang telah ditentukan dengan titik awal atau titik $\pm 0,00 \mathrm{~m}$ pada level muka tanah existing yang merupakan permukaan conblok/paving blok di masing-masing titik sondir. Sondir yang digunakan adalah Konus dengan friction cone (biconus) dengan ukuran luas penampang konus $10 \mathrm{~cm}^{2}$ dan luas selimut 150 $\mathrm{cm}^{2}$. Metode pelaksanaan dilakukan dengan menekan konus kedalam lapisan tanah secara terus menerus dengan interval kedalaman $20 \mathrm{~cm}$ (penetrasi) sampai menunjukan tahanan ujung konus (qc) dan tahan geser maksimum (f) sebesar $250 \mathrm{~kg} / \mathrm{cm}^{2}$, atau sampai kedalaman maksimum sedalam 20 meter (5). Data yang didapat dan disajikan dalam penelitian ini adalah nilai tahanan ujung konus (qc) dan total lekatan / hambatan (tf) serta ratio lokal lekatan terhadap tahanan ujung konus (f/qc) sampai kedalaman maksimum dari kapasitas alat sondir yang digunakan atau sampai maksimum kedalaman 20 meter.

\section{b. Bor Dangkal}

Pelaksanaan pemboran dilakukan pada titik bor yang telah ditentukan dengan titik awal 
atau titik \pm 0,00 $\mathrm{m}$ pada level muka tanah existing yang merupakan permukaan conblok/ paving blok setempat pada saat bor dilakukan. Pemboran adalah pemboran dangkal dengan menggunakan mata bor Iwan secara bertahap setiap kedalaman $20 \mathrm{~cm}$, tanah yang dikeluarkan dari mata bor Iwan dimasukan kedalam plastik yang telah diberi kodefikasi bor dan kedalaman. Pada kedalaman yang diinginkan dilakukan pengambilan contoh tanah tidak terganggu/tanah asli (Undisturb sample) dengan menggunakan tabung sampel, dan tabung sampel juga diberi kodefikasi kedalaman. Pada pekerjaan ini dilakukan pemboran sebanyak 1 (satu) titik bor (B) di kedalaman $30 \mathrm{~m}$ disertai pengambilan sampel tanah terganggu dan 2 tabung sampel tanah tak terganggu dilubang Bor dikedalaman 1,50 -2,00 m dan dikedalaman 3,00 m - 3,50 m untuk dilakukan pengujian dilaboratorium.

Satu set alat bor dangkal, lengkap dengan mata bor Iwan dan tabung sampel (Thin walled sampler) dengan ukuran diameter $75 \mathrm{~mm}$, panjang $45 \mathrm{~cm}$ serta tebal $2,00 \mathrm{~mm}$.

\subsection{Peralatan}

Peralatan yang digunakan dalam penelitian tanah adalah satu set alat sondir lengkap metode DCP (Dutch Cone Penetration), kapasitas 2,5 ton (250 kg/ $\left.\mathrm{cm}^{2}\right)$ dilengkapi dengan friction cone (biconus). Alat sondir terdiri atas:

a. Mesin sondir ringan (2 ton) atau mesin sondir berat (10 ton),

b. Seperangkat pipa sondir lengkap dengan batang dalam, sesuai kebutuhan dengan panjang masing masing 1 meter,

c. Manometer masing masing 2 buah dengan kapasitas :

- Untuk Sondir ringan menggunakan $0 \mathrm{~s} / \mathrm{d}$ $50 \mathrm{~kg} / \mathrm{cm}^{2}$ dan $0 \mathrm{~s} / \mathrm{d} 250 \mathrm{~kg} / \mathrm{cm}^{2}$.

- Untuk Sondir berat menggunakan $0 \mathrm{~s} / \mathrm{d} 50$ $\mathrm{kg} / \mathrm{cm}^{2}$ dan $0 \mathrm{~s} / \mathrm{d} 600 \mathrm{~kg} / \mathrm{cm}^{2}$.

d. Konus dan bikonus

e. Empat buah angker dengan perlengkapan (angker daun dan spiral).

f. Kunci-kunci pipa, alat-alat pembersih, oli dan minyak hidrolik.

Satu set alat bor dangkal, lengkap dengan mata bor Iwan dan tabung sampel (Thin walled sampler) dengan ukuran diameter $75 \mathrm{~mm}$, panjang $45 \mathrm{~cm}$ serta tebal $2,00 \mathrm{~mm}$.

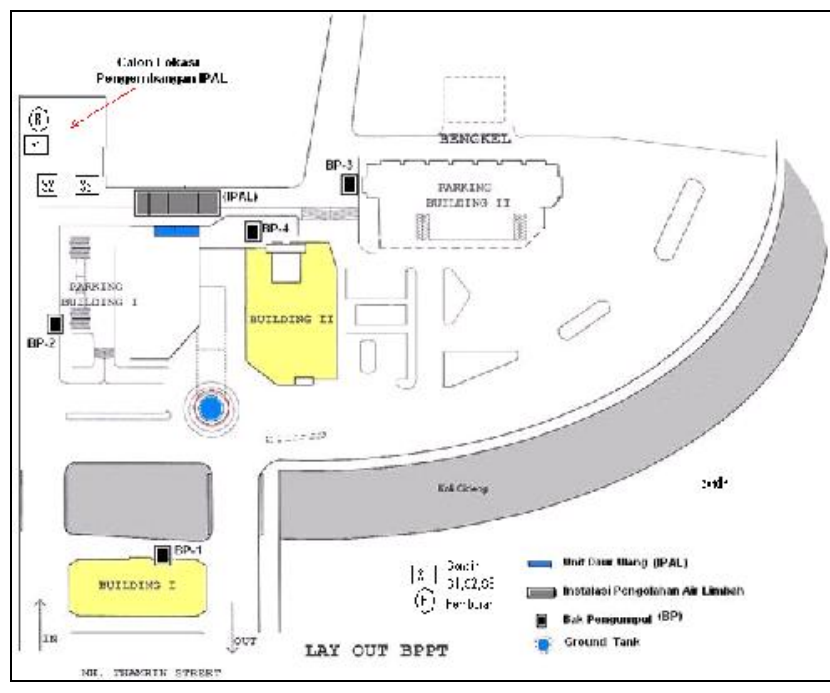

Gambar 1. Lokasi Penelitian Sondir dan Pemboran
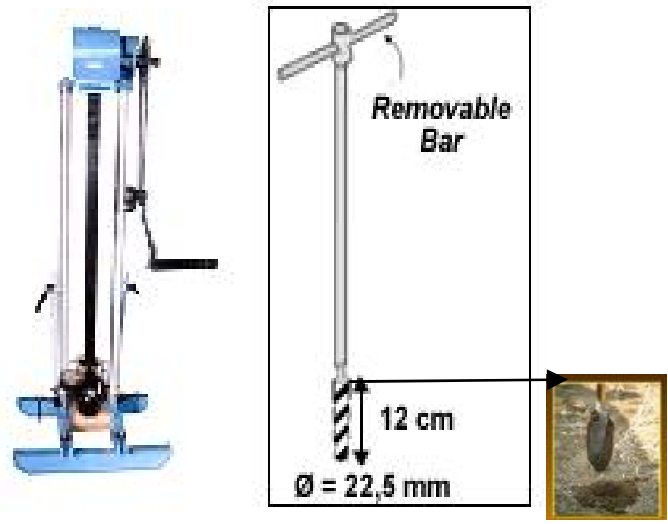

Gambar 2: Alat Sondir dan Alat Bor

\section{KEGIATAN PENELITIAN}

Penelitian dilakukan pada tanggal 27-28 September 2010 dan kegiatan ini meliputi:

a. Pekerjaan sondir. Sondir dilakukan dengan menggunakan satu set alat sondir lengkap yang berkapasitas 2,5 ton di 3 (tiga) titik sondir yang telah ditentukan dilokasi bangunan yaitu titik sondir (S-1, S-2 dan S3).

b. Pekerjaan pemboran. Pemboran merupakan pemboran dangkal dilakukan pada 1 titik bor (B) diantara lokasi titik sondir, untuk melihat secara visual kondisi lapisan tanah pada lapisan permukaan sampai dikedalaman 4,00 $\mathrm{m}$ dengan melakukan pengambilan sampel tanah terganggu (disturbed) dan sampel tanah asli /sampel tanah tidak terganggu (undisturb) sejumlah 2 tabung sampel pada lobang Bor di kedalaman $1,50 \mathrm{~m}-2,00 \mathrm{~m}$ dan di 
kedalaman 3,00m-3,50m yang akan dilakukan tes di laboratorium (5) .

Pelaksanaan pemboran:

Untk lapisan permukaan yang terdiri dari lapisan lempung, lanau atau pasir dapat dimulai dari bor spiral dari common auger(17/8"), closed spiral auger( $\left.2^{1 / 2} 2^{\prime \prime}\right)$, atau open spiral auger dimana dilakukan dengan pemboran sistem kering. Pemboran dengan spiral ini dilakukan pada kedalaman $40 \mathrm{~cm}$ sampai 2 meter atau 3 meter.

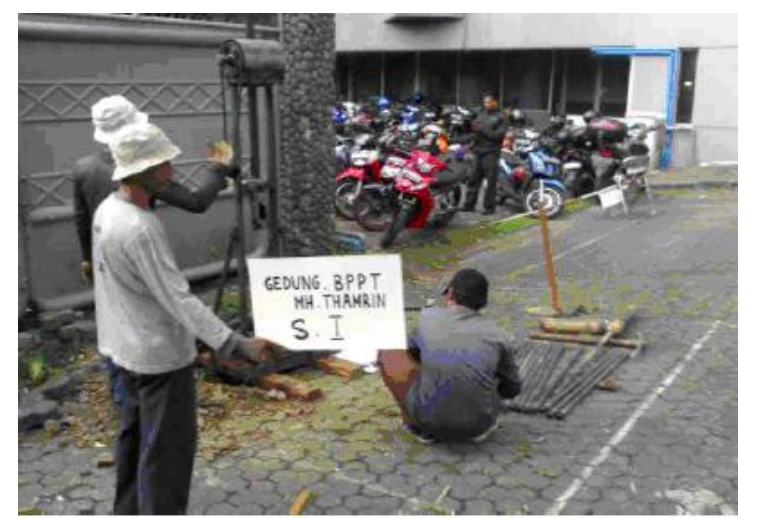

Gambar 3. Pelaksanaan sondir dan pemboran

c. Analisa laboratorium dan Interpretasi hasil uji sondir. Sampel tanah dari pemboran di analisa di laboratorium dan hasilnya dibandingkan dengan parameter tanah yang dihasilkan secara empiris dari hasil tes sondir yang dikaitkan parameter lainnya. Interpretasi masing-masing log borhole perlapisan tanah, dikaitkan dengan jenis dan klasifikasi tanah secara Unified maupun AASTHO. Kemudian membuat profil lapisan tanah dari log borehole satu ke log borhole yang lain, sehingga dapat ditentukan pemetaan per lapisan tanah yang sejenis, pada potongan melintang yang dikehendaki. Menyimpul-kan hasil tes permeabilitas, statigrafi tanah dan sifat tanah serta menentukan kapasitas daya dukung tanah dan daya dukung tiang secara umum.

\section{KELEBIHAN DAN KEKURANGAN SONDIR DAN PEMBORAN}

\subsection{Sondir}

Uji sondir merupakan alat yang sederhana, praktis, dengan kelebihan yaitu : cepat, murah, menghasilkan data yang akurat dan detail. Sondir sangat cocok untuk tanah di Indonesia karena kondisi tanah di Indonesia sebagian besar berupa lempung lanauan.
Sedangkan kekurangannya adalah : tidak dapat diperoleh sampel, untuk uji laboratorium maupun untuk klasifikasi visual, dan tidak dapat menembus lapisan batuan. Untuk daerah-daerah tertentu dimana lapisan tanah berupa pasir maka alat ini kurang representatif dan tidak dapat menembus lensa gravel/pasir yang cukup tebal dan padat, sehingga bila dibawah lensa pasir terdapat tanah lunak maka sulit untuk terdeteksi.

Pada tanah pasir pengaruh tekanan air pori selama penetrasi pada kecepatan penetrasi yang normal sangat kecil dan diabaikan, sehingga hasil sondir dalam keadaan fully drained, sedangkan pada tanah lempung plastis hasil uji sondir lebih kearah fully undrained dan bila jenis tanah diantara kedua jenis diatas dapat memberikan hasil untuk keadaan fully drained dan fully undrained ${ }^{(6)}$.

\subsection{Pemboran}

Uji bor merupakan pengujian lapangan yang paling baik dan akurat untuk segala jenis tanah dan diperlukan untuk test-test yang lain, sedangkan kerugiannya adalah: mahal, berat (perlu alat angkut yang memadahi), waktu pelaksanaan lama dan kurang cocok untuk bangunan sederhana. Setiap pelaksanaan test pemboran selalu diikuti dengan uji penetrasi baku (Standar Penetration Test), yang perlu diperhatikan adalah faktor-faktor yang mempengaruhi harga N-SPT yaitu :

Jumlah energi yang mencapai sampel, ditentukan oleh: jenis hammer, jenis dan panjang rod, variasi tinggi jatuh palu, jumlah lilitan tali dan umur tali. Kondisi tegangan tanah dasar lubang bor bor, ditentukan oleh: kelalaian menjaga tekanan hidrostatis, tinggi air diluar dan didalam harus sama; metode pengeboran dan stabilisasi dinding, serta diameter dinding.

Faktor-faktor lain yang mempengaruhi pemboran, seperti: pembersihan dasar lubang bor, kelalaian menghitung jumlah tumbukan dan pemakaian sampel yang sudah rusak.

\section{Hasil Penelitian}

\subsection{Pengujian Sondir (CPT)}

Dari hasil uji sondir didapatkan nilai-nilai karakteristik tanah secara umum sebagai disajikan pada tabel 1, hasil sondir memberikan informasi yang berhubungan dengan kedalaman penyondiran, kedalaman lapisan tanah keras untuk nilai $\mathrm{qc} \geq 100 \mathrm{~kg} / \mathrm{cm}^{2}$ dan besar nilai kumulatif total lekatan/friction (tf) sampai di kedalaman lapisan tanah keras serta nilai daya dukung sondir (qc) pada daerah lapisan permukaan. 
Tabel : 1. Hasil Sondir S-1, S-2 dan S-3

\begin{tabular}{|c|c|c|c|c|}
\hline $\begin{array}{c}\text { Titik } \\
\text { Sondir }\end{array}$ & $\begin{array}{c}\text { Kedalaman } \\
\text { Sondir }\end{array}$ & $\begin{array}{c}\text { Kedalaman } \\
\text { untuk nilai qc } \\
\geq \mathbf{1 0 0} \mathbf{~ k g} / \mathbf{c m}^{\mathbf{2}}\end{array}$ & $\begin{array}{c}\text { Nilai tf } \\
\text { pada nilai qc } \\
\geq 100 \mathbf{~ k g} / \mathbf{c m}^{\mathbf{2}}\end{array}$ & $\begin{array}{c}\text { Nilai qc pada kedalaman } \\
\mathbf{1 , 0 0 ~} \mathbf{~} \mathbf{- 2 , 0 0 ~} \mathbf{~ m}\end{array}$ \\
\hline 1 & 2 & 3 & 4 & 5 \\
\hline $\mathrm{S}-1$ & $27,00 \mathrm{~m}$ & $26,50 \mathrm{~m}$ & $>>2000 \mathrm{~kg} / \mathrm{cm}$ & Sangat kecil \\
\hline $\mathrm{S}-2$ & $27,00 \mathrm{~m}$ & $26,20 \mathrm{~m}$ & $>>2000 \mathrm{~kg} / \mathrm{cm}$ & Sangat kecil \\
\hline $\mathrm{S}-3$ & $27,20 \mathrm{~m}$ & $26,60 \mathrm{~m}$ & $>>2000 \mathrm{~kg} / \mathrm{cm}$ & Sangat kecil \\
\hline
\end{tabular}

Hasil uji dari ke 3 titik sondir yaitu titik sondir S-1, S-2 dan S-3 memperlihatkan karakteristik lapisan tanah yang relatif hampir seragam (gambar hasil sondir), kedalaman lapisan tanah keras cukup dalam. Untuk nilai daya dukung konus sondir $\geq 100 \mathrm{~kg} / \mathrm{cm}^{2}$, bervariasi dikedalaman antara $26,20 \mathrm{~m}$ sampai $26,60 \mathrm{~m}$ yang mendekati akhir sondir yaitu di kedalaman antara $27,00 \mathrm{~m}$ sampai $27,20 \mathrm{~m}$. Nilai lekatan tanah untuk ke 3 titik sondir yang digambarkan dari total kumulatif nilai lekatan, yaitu:

- nilai $2000 \mathrm{~kg} / \mathrm{cm}$ terdapat dikedalaman antara $18,20 \mathrm{~m}-20,20 \mathrm{~m}$

- nilai $>2000 \mathrm{~kg} / \mathrm{cm}$ terdapat dilapisan tanah keras yaitu di kedalaman antara $26,20 \mathrm{~m}$ sampai $26,60 \mathrm{~m}$.

Nilai daya dukung konus sondir lapisan tanah permukaan sampai di kedalaman $5,00 \mathrm{~m}$ berkisar pada rentang nilai antara $1 \mathrm{~kg} / \mathrm{cm}^{2}$ sampai 7 $\mathrm{kg} / \mathrm{cm}^{2}$ dengan rata-rata $3,92 \mathrm{~kg} / \mathrm{cm}^{2}$ dan dikedalaman dibawah $5,00 \mathrm{~m}$ sampai dikedalaman 10,00 m dengan rentang nilai daya dukung antara $6 \mathrm{~kg} / \mathrm{cm}^{2}$ sampai $14 \mathrm{~kg} / \mathrm{cm}^{2}$ dengan rata-rata $9,78 \mathrm{~kg} / \mathrm{cm}^{2}$. Dibawah kedalaman $10,00 \mathrm{~m}$, nilai daya dukung secara gradual bertambah besar sampai dikedalaman lapisan tanah keras yaitu dikedalaman antara $26,20 \mathrm{~m}$ sampai $26,60 \mathrm{~m}$.

\subsection{Pemboran}

Pemboran dilakukan dengan pemboran dangkal pada lapisan permukaan sampai dikedalaman 4,00 m pada 1 (satu) titik bor (B) sesuai dengan gambar denah titik bor. Pemboran ini untuk tujuan melihat secara visual karakteristik lapisan tanah, jenis tanah, warna tanah dan pengambilan sampel tanah terganggu (disturbed) dan tanah tidak terganggu (undisturb) sejumlah 2 tabung sampel di titik Bor di kedalaman 1,50 m $2,00 \mathrm{~m}$ dan dikedalaman $3,00 \mathrm{~m}-3,50 \mathrm{~m}$ pada lapisan tanah permukaan. Untuk mengetahui karakteristik sampel tanah dilakukan tes dilaboratorium sebagai disajikan pada tabel 2 dan bor log dapat dilihat pada lampiran 2.

Tabel 2: Tabel pengambilan sampel Tanah asli (Undisturb)

\begin{tabular}{|c|c|l|}
\hline $\begin{array}{c}\text { Titik } \\
\text { Bor }\end{array}$ & $\begin{array}{c}\text { Kedalaman } \\
\text { sample } \\
\text { undisturb }\end{array}$ & \multicolumn{1}{|c|}{ Keterangan } \\
\hline \hline \multirow{1}{*}{ B } & $1,50 \mathrm{~m}-2,00 \mathrm{~m}$ & $\begin{array}{l}\text { Lempung / Lanau } \\
\text { Warna Coklat } \\
\text { kehitaman } \\
\text { Lunak }\end{array}$ \\
\cline { 2 - 3 } & $3,00 \mathrm{~m}-3,50 \mathrm{~m}$ & $\begin{array}{l}\text { Lempung / Lanau } \\
\text { Warna Coklat } \\
\text { kehitaman } \\
\text { Lunak }\end{array}$ \\
\hline
\end{tabular}

\subsection{Pengujian Di Laboratorium}

Pengujian di laboratorium dilakukan pada sampel tanah terganggu (disturbed) dan sampel tanah tidak terganggu (Undisturb) dari 1 (satu) titik bor dangkal dimana sampel tanah terganggu yang berasal dari mata bor Iwan. Penelitian dilakukan untuk diskripsi tanah secara visual, yaitu jenis tanah, warna tanah dan kekerasan tanah. Sedangkan analisa laboratorium dilakukan terhadap 2 tabung sampel tanah tidak terganggu yang berasal dari 1 titik bor dengan kedalaman sampel $1,50 \mathrm{~m}-2,00 \mathrm{~m}$ dan dikedalaman $3,00 \mathrm{~m}-$ $3,50 \mathrm{~m}$. Penelitian untuk mengetahui karakteristik tanah meliputi index properties, dan mekanikal properties. Prosedur analisa mengikuti persyaratan ASTM dan SNI. yang terdiri atas penentuan: 1) kadar air $(w), 2)$ berat isi tanah $(\gamma)$, 3) berat isi kering $\left(\gamma_{\mathrm{d}}\right)$, 4) Specific Gravity (Gs), 5) Atterberg limit (LL dan PL), 6) Uji Triaxial UU, 7) Konsolidasi tes, 8) Analisa butir dan hydrometer dan hasil tes disajikan pada tabel 3.

Pada tabel 4 menunjukkan kadar air asli tanah dilapangan cukup tinggi berkisar pada nilai antara $71,57 \%$ - $98,73 \%$ dengan rata-rata $85,15 \%$. Karakteristik tanah dalam kondisi pada 
batas plastis mendekati batas cair (liquid limit) dengan nilai berkisar antara 94,62\% - 99,93\% dengan rata-rata $97,28 \%$. Jenis tanah lapisan permukaan pada titik bor sampai di kedalaman 3,50m merupakan jenis lanau dengan persentase antara $55 \%-60 \%$ dengan rata-rata $57,50 \%$ dan lempung dengan persentase antara 18\%-23\% dengan rata-rata $20,50 \%$.

Tabel 3 : Hasil Uji Laboratorium sampel bor B

\begin{tabular}{|c|c|c|c|}
\hline Jenis Uji & $\begin{array}{c}\text { Simbol dan } \\
\text { satuan }\end{array}$ & $\begin{array}{c}\text { Kedalaman } \\
1,50-2,00 \mathrm{~m}\end{array}$ & $\begin{array}{c}\text { Kedalaman } \\
3,00-3,50 \mathrm{~m}\end{array}$ \\
\hline \multirow{4}{*}{$\begin{array}{c}\text { INDEX } \\
\text { PROPERTIES }\end{array}$} & $w \%$ & 71,57 & 98,73 \\
\hline & $\gamma \mathrm{t} / \mathrm{m}^{3}$ & 1,55 & 1,45 \\
\hline & $\mathrm{e}$ & 1,94 & 2,64 \\
\hline & Gs & 2,67 & 2,66 \\
\hline \multirow{3}{*}{ ATTERBERG } & LL \% & 94,62 & 99,93 \\
\hline & $\mathrm{PL} \%$ & 63,44 & 64,22 \\
\hline & $\mathrm{PI} \%$ & 31,18 & 35,70 \\
\hline \multirow{4}{*}{ BUTIRAN (\%) } & $\mathrm{Kr} \%$ & 2 & 2 \\
\hline & Ps \% & 20 & 20 \\
\hline & Lanau \% & 55 & 60 \\
\hline & $\begin{array}{c}\text { Lempung } \\
\%\end{array}$ & 23 & 18 \\
\hline \multirow{2}{*}{$\begin{array}{l}\text { TRIAXIAL } \\
\text { TEST }\end{array}$} & $\mathrm{C} \mathrm{kg} / \mathrm{cm}^{2}$ & 0,10 & 0,11 \\
\hline & $\varphi^{\circ}$ & 6,56 & 5,99 \\
\hline \multirow{3}{*}{ CONSOLIDASI } & Cc & 0,67 & 0,95 \\
\hline & $\mathrm{Pc} \mathrm{kg} / \mathrm{cm}^{2}$ & 1,50 & 1,60 \\
\hline & $\mathrm{Cv} \mathrm{cm}^{2} / \mathrm{det}$ & $0,79 \times 10^{-3}$ & $0,87 \times 10^{-3}$ \\
\hline
\end{tabular}

Tabel 4 : Rentang nilai dari parameter tanah titik Bor B

\begin{tabular}{|c|c|c|c|c|}
\hline Sifat & Simbol & Satuan & Rentang nilai & $\begin{array}{c}\text { Rata-rata } \\
\text { nilai }\end{array}$ \\
\hline 1 & 2 & 3 & 4 & 5 \\
\hline Kadar air & $\mathrm{W}$ & $\%$ & $71,57-98,73$ & 85,15 \\
\hline Berat isi tanah & $\gamma$ & $\mathrm{t} / \mathrm{m}^{3}$ & $1,45-1,55$ & 1,50 \\
\hline Angka pori & $\mathrm{e}$ & & $1,94-2,64$ & 2,29 \\
\hline Spesific grafity & Gs & & $2,66-2,67$ & 2,67 \\
\hline Liquit limit & LL & $\%$ & $94,62-99,93$ & 97,28 \\
\hline Plastis limit & $\mathrm{PL}$ & $\%$ & $63,44-64,22$ & 63,83 \\
\hline Plastis index & $\mathrm{PI}$ & $\%$ & $31,18-35,7$ & 33,44 \\
\hline Kerikil & $\mathrm{Kr}$ & $\%$ & $2-2$ & 2,00 \\
\hline Pasir & Ps & $\%$ & $20-20$ & 20,00 \\
\hline Lanau & Lanau & $\%$ & $55-60$ & 57,50 \\
\hline Lempung & $\begin{array}{c}\text { Lempun } \\
\mathrm{g}\end{array}$ & $\%$ & $18-23$ & 20,50 \\
\hline Kohesi & $\mathrm{C}$ & $\mathrm{kg} / \mathrm{cm}^{2}$ & $0,1-0,11$ & 0,11 \\
\hline $\begin{array}{l}\text { Sudut geser } \\
\text { dalam }\end{array}$ & $\varphi$ & Derajat ${ }^{\circ}$ & $5,99-6,56$ & 6,28 \\
\hline Koef konsollidasi & Cc & & $0,67-0,95$ & 0,81 \\
\hline Prakonsolidasi & $\mathrm{Pc}$ & $\mathrm{kg} / \mathrm{cm}^{2}$ & $1,5-1,6$ & 1,55 \\
\hline $\begin{array}{l}\text { Koef } \\
\text { pemampatan }\end{array}$ & $\mathrm{Cv}$ & $\mathrm{cm}^{2} / \mathrm{det}$ & $0,79 \times 10^{-3}-0,87 \times 10^{-3}$ & $0,83 \times 10^{-3}$ \\
\hline
\end{tabular}




\subsection{Hasil Evaluasi}

a. Daya dukung izin pondasi dangkal. Dengan memperhatikan nilai-nilai hasil sondir dan hasil tes laboratorium untuk penggunaan pondasi bangunan yang cukup berat tidak disarankan penggunaan pondasi langsung atau pondasi dangkal, dimana nilai daya dukung sampai dikedalaman $5,00 \mathrm{~m}$ sangat kecil berkisar antara $1 \mathrm{~kg} / \mathrm{cm}^{2}$ sampai 7 $\mathrm{kg} / \mathrm{cm}^{2}$ dengan rata-rata $3,92 \mathrm{~kg} / \mathrm{cm}^{2}$.

\section{b. Daya dukung pondasi tiang.}

Untuk pengggunaan pondasi tiang tunggal yang ditumpu pada lapisan tanah keras dengan memasukan ujung tiang kedalaman lapisan tanah keras yang cukup dalam, di kedalaman antara $26,20 \mathrm{~m}$ sampai $26,60 \mathrm{~m}$, dengan daya dukung izin tekan tanah untuk beberapa type pondasi tiang tunggal dengan beban vertikal sebagai salah satu alternatif disajikan pada tabel 5 .

Untuk pengggunaan pondasi tiang tunggal dikedalaman 20,00 $\mathrm{m}$ dengan nilai daya dukung konus sondir berkisar antara 30 $\mathrm{kg} / \mathrm{cm}^{2}$ sampai $70 \mathrm{~kg} / \mathrm{cm}^{2}$ dengan nilai kumulatif lekatan tanah sebesar $2000 \mathrm{~kg} / \mathrm{cm}$, maka daya dukung izin tekan tanah untuk beberapa type pondasi tiang tunggal dengan beban vertikal sebagai salah satu alternatif disajikan pada tabel 6 .

Tabel 5: Daya Dukung izin tekan tanah untuk pondasi tiang tunggal

Di kedalaman antara $26,20 \mathrm{~m}$ sampai $26,60 \mathrm{~m}$

\begin{tabular}{|c|c|c|}
\hline $\begin{array}{c}\text { Jenis } \\
\text { pondasi }\end{array}$ & $\begin{array}{c}\text { Ukuran } \\
\text { pondasiTiang } \\
\text { (cm) }\end{array}$ & $\begin{array}{c}\text { Daya } \\
\text { dukung izin } \\
\text { Tekan }\end{array}$ \\
\hline Tiang & $20 \times 20$ & 41,7 ton \\
Pancang & $25 \times 25$ & 55,0 ton \\
& $28 \times 28 \times 28$ & 42,0 ton \\
\hline & $\varnothing 30$ & 54,4 ton \\
Tiang Bor & $\varnothing 35$ & 66,6 ton \\
& $\varnothing 40$ & 79,7 ton \\
\hline
\end{tabular}

Tabel 6 : Daya Dukung izin tekan tanah untuk pondasi tiang tunggal

Di kedalaman 20,00 m

\begin{tabular}{|c|c|c|}
\hline $\begin{array}{c}\text { Jenis } \\
\text { pondasi }\end{array}$ & $\begin{array}{c}\text { Ukuran } \\
\text { pondasiTiang } \\
\text { (cm) }\end{array}$ & $\begin{array}{c}\text { Daya dukung } \\
\text { izin Tekan }\end{array}$ \\
\hline Tiang & $20 \times 20$ & 25,40 ton \\
Pancang & $25 \times 25$ & 32,9 ton \\
& $28 \times 28 \times 28$ & 25,9 ton \\
\hline \multirow{2}{*}{ Tiang Bor } & $\varnothing 30$ & 32,0 ton \\
& $\varnothing 35$ & 38,6 ton \\
& $\varnothing 40$ & 45,6 ton \\
\hline
\end{tabular}

\section{KESIMPULAN}

a. Hasil pengukuran pengukuran sondir menunjukkan keadaan sebagai berikut:

- Dari ke 3 titik sondir S.1, S.2 dan S.3 memperlihatkan nilai hampir seragam dan lapisan tanah keras terdapat dikedalaman $26,20 \mathrm{~m}-26,60 \mathrm{~m}$. Ketebalan lapisan tanah keras tidak dapat diketahui dari hasil uji sondir karena kemampuan sondir ringan maximum terbatas.

- Nilai daya dukung konus sondir, pada perbedaan kedalaman tiap 5 meter meningkat secara gradual sampai lapisan tanah keras dikedalaman 26,60 m.

- Nilai lekatan tanah untuk ke 3 titik sondir dikedalaman 18,20 m - 20,20 m adalah sebesar $2000 \mathrm{~kg} / \mathrm{cm}$ dan kedalaman di bawahnya sampai lapisan tanah keras nilainya $>>2000 \mathrm{~kg} / \mathrm{cm}$.

b. Pengamatan visual dari tanah hasil pemboran merupakan lapisan tanah lempung / lanau warna coklat kehitaman lunak.

C. Pengujian Laboratorium dari titik pemboran (B) dilakukan pada tanah terganggu (Disturb) dikedalaman 1,50 m-2,00 m dan tanah tidak terganggu (Undisturb) dikedalaman 3,00m 3,50 m masing-masing sejumlah 2 tabung. Hasil analisa sampel yaitu:

- Kadar air asli tanah dilapangan cukup tinggi berkisar pada nilai antara 71,57 $\%$ - 98,73 \% dengan rata-rata $85,15 \%$ dan tanah dalam kondisi pada batas plastis mendekati batas cair (liquid limit) dengan nilai bekisar antara 94,62 \% $99,93 \%$ dengan rata-rata $97,28 \%$.

- Jenis tanah lapisan permukaan pada titik bor sampai dikedalaman $3,50 \mathrm{~m}$ merupakan jenis lanau dengan persentase antara $55 \%$ - $60 \%$ dengan rata-rata $57,50 \%$ dan lempung dengan persentase antara $18 \%$ - $23 \%$ dengan rata-rata 20,50 $\%$.

- Untuk pondasi bangunan yang cukup berat tidak disarankan menggunakan pondasi langsung atau pondasi dangkal, dimana nilai daya dukung sampai dikedalaman $5,00 \mathrm{~m}$ sangat kecil yaitu $1 \mathrm{~kg} / \mathrm{cm}^{2}-7$ $\mathrm{kg} / \mathrm{cm}^{2}$ dengan rata-rata $3,92 \mathrm{~kg} / \mathrm{cm}^{2}$.

- Alternatif pondasi bangunan IPAL adalah: penggunaan pondasi tiang tunggal yang ditumpu pada lapisan tanah keras dengan memasukan ujung tiang kedalaman lapisan tanah keras yang cukup dalam, dikedalaman antara $26,20 \mathrm{~m}$ sampai 26,60 $\mathrm{m}$ atau penggunaan pondasi tiang tunggal 
dikedalaman 20,00 m dengan nilai daya dukung konus sondir berkisar antara 30 $\mathrm{kg} / \mathrm{cm}^{2}$ sampai $70 \mathrm{~kg} / \mathrm{cm}^{2}$ dengan nilai kumulatif lekatan tanah sebesar 2000 $\mathrm{kg} / \mathrm{cm}$.

\section{DAFTAR PUSTAKA}

1. R.F Craig, 1987, Soil Mechanics, Van Nostroad Reinhold (UK).

2. Mitchell, R. J. 1983. Earth Structures Engineering, Allen \& Unwin, Inc., Boston.
3. Hardiyatmo, Hary Christady, 1996, Teknik Pondasi 1, PT. Gramedia Pustaka

4. SNI 2827 - 2008, Cara uji penetrasi lapangan dengan alat sondir.

5. ^ASTM D1587-00(2007)e1 Standard Practice for Thin-Walled Tube Sampling of Soils for Geotechnical.

6. Muhrozi, Soilt Test, Masalah dan Aplikasinya pada tanah Lunak, 2002, Lab. Mekanika Tanah Jurusan Teknik Sipil Universitas Diponegoro.

\section{LAMPIRAN}

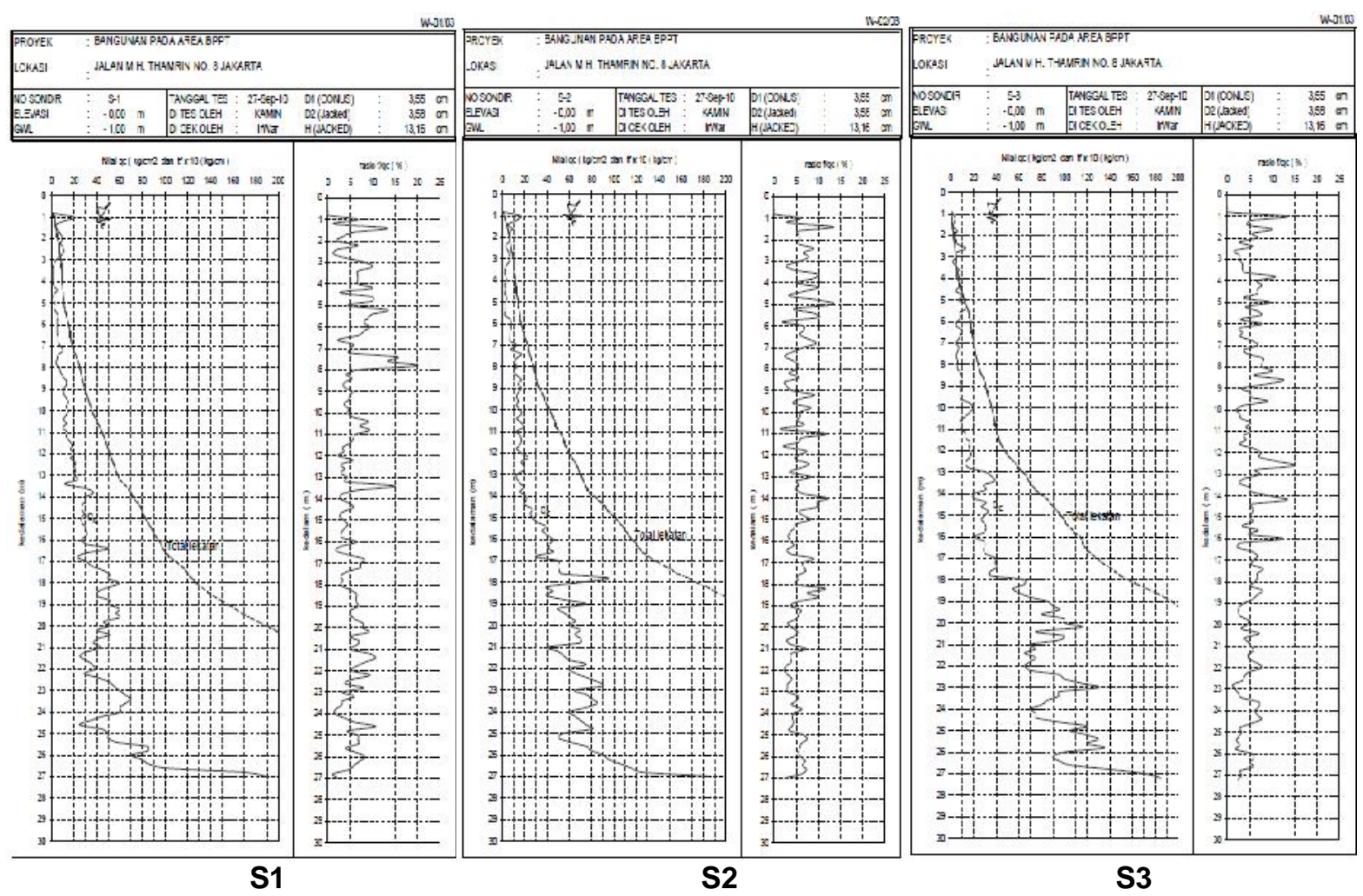

Gambar 1. Grafik sondir di 3 lokasi (S1,S2,S3) 


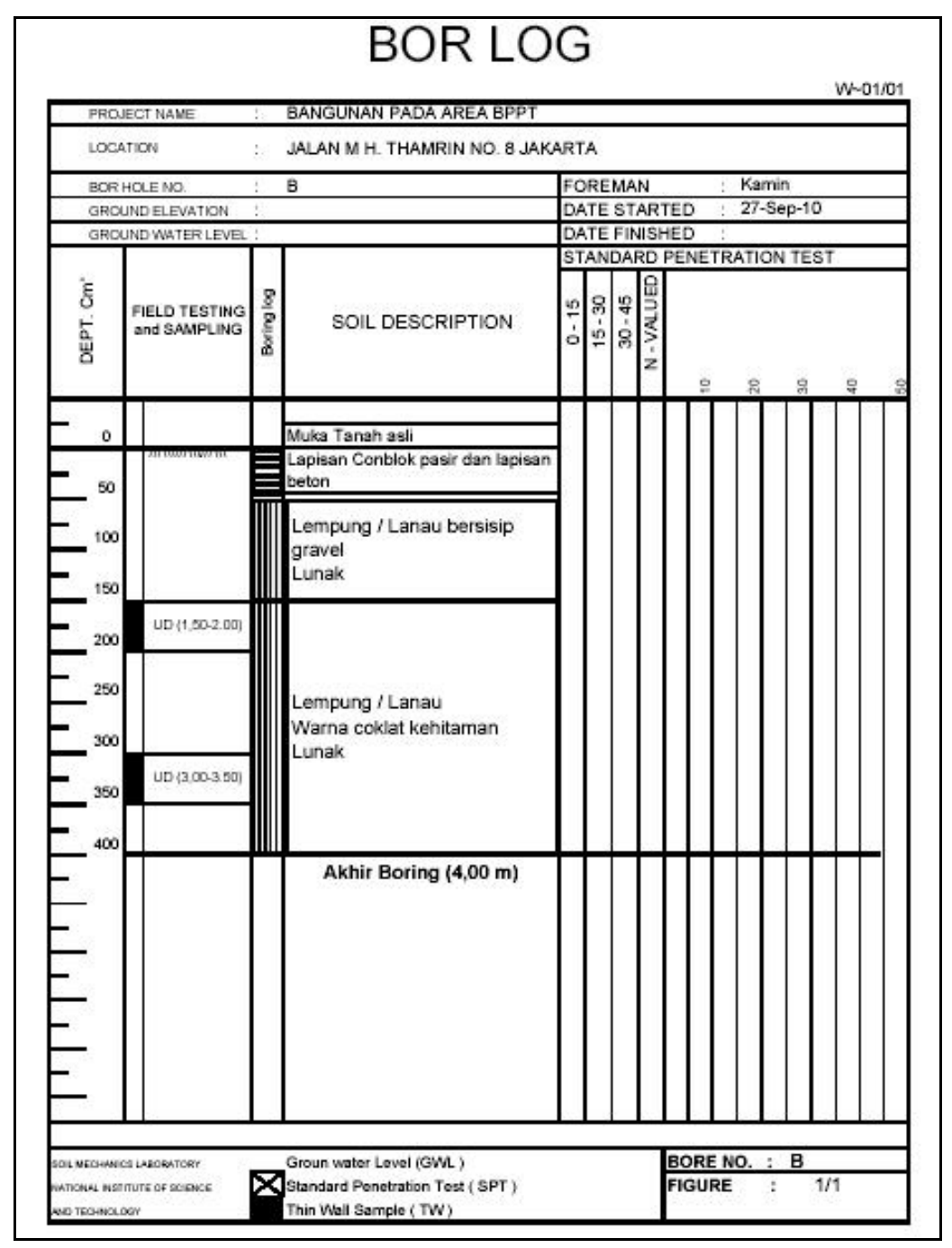

Gambar 2. Bor Log di lokasi B 